DOI https://doi.org/10.15589/znp2020.1(479).5

UDC 621.45 .034

\title{
RESEARCH OF LOW-EMISSION ASSOCIATED GAS COMBUSTION IN THE GAS TURBINE ENGINE OF A FLOATING PRODUCTION, STORAGE AND OFFLOADING SYSTEM
}

\section{ДОСЛІДЖЕННЯ ПРОЦЕСІВ НИЗЬКОЕМІСІЙНОГО СПАЛЮВАННЯ ПОПУТНОГО ГАЗУ В ГТД В СКЛАДІ ПЛАВУЧОЇ СИСТЕМИ ВИДОБУТКУ, ЗБЕРІГАННЯ ТА ВИВАНТАЖЕННЯ НАФТОПРОДУКТІВ}

\author{
Serhiy I. Serbin \\ serhiy.serbin@nuos.edu.ua \\ ORCID: 0000-0002-3423-2681 \\ Wang YunFei \\ 845619299@qq.com
}

\author{
S. I. Serbin, \\ D. Sc., Prof., \\ Wang YunFei, \\ Postgraduate Student
}

\author{
Admiral Makarov National University of Shipbuilding, Mykolaiv \\ Начіональний університет кораблебудування імені адмірала Макарова, м. Миколаїв
}

\begin{abstract}
The analysis of the possibilities of organization of low-emission associated gas combustion in the combustion chamber of a gas turbine engine with a capacity of $25 \mathrm{MW}$, which works as part of floating production, storage and offloading (FPSO) system is carried out.

One of the significant problems that solved when using the gas turbine technology at FPSO is to satisfy the international environmental requirements, especially for emissions of toxic components, such as carbon and nitrogen oxides.

An effective way of organizing a workflow in a gas turbine low-emission combustion chamber operating on different gaseous fuels is proposed. In order to increase the efficiency of the processes in the gas turbine chamber, it is proposed to use the ideas of pre-mixing of gaseous fuels with air in axial-radial swirlers, as well as significant leaning of the fuel-air mixture in the volume of the combustion chamber.

A mathematical model of a low-emission gas turbine combustion chamber has been developed, which allows predicting the environmental parameters of a fuel-burning device when using associated gas.

Three-dimensional mathematical model of gaseous fuels combustion in a low-emission gas turbine combustion chamber contains the following equations: continuity, conservation of momentum and energy, transfer of chemical components, formation and decomposition of nitrogen oxides.

The obtained results showed certain deterioration in the environmental parameters of the combustion chamber when switching from natural to associated gas and the need for further modification of the combustion chamber with lean and partially premixed mixture of fuel and air when using associated gas on the FPSO vessels.

Key words: gas turbine engine; low-emission combustor; associated gas; mathematical modeling.
\end{abstract}

Анотація. Проведено аналіз можливостей організації низькоемісійного сталювання попутного газу в камері згоряння газотурбінного двигуна потужністю 25 МВт, що працює в складі плавучої системи видобутку, зберігання та вивантаження нафтопродуктів (FPSO).

Одна з істотних проблем, яка вирішується при використанні газотурбінної техніки в складі FPSO, - задоволення екологічних вимог міжнародних організацій, особливо щодо викидів токсичних компонентів, таких як оксиди вуглецю та азоту.

Запропоновано ефективний спосіб організації робочого процесу в газотурбінній низькоемісійній камері згоряння, що працює на різних видах газоподібного палива. 3 метою підвищення ефективності процесів у газотурбінній камері пропонується використовувати ідеї попереднього перемішування газоподібного палива із повітрям в аксіально-радіальних завихрювачах, а також значного збіднення паливо-повітряної суміші в об’ ємі камери згоряння.

Розроблено математичну модель газотурбінної камери згоряння з низьким рівнем викидів токсичних компонентів, яка дає змогу передбачити екологічні параметри паливоспалюючого пристрою в процесі використання попутного газу.

Тривимірна математична модель вигоряння газоподібного палива в низькоемісійній камері згоряння ГТД містить рівняння: нерозривності, збереження кількості руху та енергії, переносу хімічних компонентів, утворення і розкладання оксидів азоту. 


\section{ЕНЕРГЕТИЧНЕ МАШИНОБУДУВАННЯ №1-2020}

Отримані результати показали певне погіршення екологічних параметрів камери згоряння при переході з природного на попутний газ та необхідність подальшої модифікації камери згоряння з попереднім частковим змішуванням палива та повітря при використанні попутного газу в системах FPSO.

Отримано нові знання щодо організації робочого процесу в низькоемісійних камерах згоряння ГТД та вигоряння вищих вуглеводнів у газотурбінній камері.

Ключові слова: газотурбінний двигун; низькоемісійна камера згоряння; попутний газ; математичне моделювання.

\section{FORMULATION OF THE PROBLEM}

Currently, due to the global development of oil and gas production in offshore fields located not only near the coast, but also in the oceans, there is a tendency to use a floating production, storage and offloading system. FPSO produces crude oil and gas at sea. It is one of a number of different types of floating systems used today in the oil and gas industry. Outwardly, it resembles a vessel, but it was designed completely differently and carries not only all the necessary products and technological equipment, but also tanks for crude oil extracted from wells on the seabed. It moors for a long time in the required place and connects to the wells with a flexible riser. 183 FPSO vessels operated in the offshore fleet at the end of 2018, and another 55 such vessels will be built by 2022 [1;2].

The processes occurring in FPSO are associated with significant energy consumption. The composition and characteristics of marine infrastructure facilities vary widely, but the main drive engines are usually gas turbine engines (GTE) and four-stroke diesel engines. GTEs have become widespread due to the large unit power and compactness [3].

One of the significant problems that solved when using the gas turbine technology at FPSO is to satisfy the international environmental requirements, especially for emissions of toxic components, such as carbon and nitrogen oxides [4]. Many gas turbine companies deal with issues of engines ecology and their applicability to FPSO systems, and options are being considered for both dual-fuel engines and their adaptation for associated gas.

Research on ways to improve the combustion chambers emission characteristics that will solve the problem of creating high-efficiency FPSO gas turbine modules and satisfy the requirements of the next generation of energy systems is an urgent problem, the solution of which will have social and economic effects.

\section{ANALYSIS OF RECENT RESEARCH AND PUBLICATIONS}

The technical literature pays considerable attention to the description of FPSO technical systems, including the use of gas turbine engines $[3 ; 5 ; 6]$. The review of work [7] indicates applicability of: three $27.5 \mathrm{MW}$ gas turbine generators on FPSO's Pioneiro de Libra, four 36 MW gas turbine generators on FPSO's Cidade de Itajaí, three $21 \mathrm{MW}$ gas turbine generators on FPSO's
Armada Olombendo, two $16 \mathrm{MW}$ gas turbine generators on FPSO's Global Producer III, $4 \mathrm{MW}$ gas turbine generators on FPSO's Dhirubhai-1, two $42 \mathrm{MW}$ gas turbine generators on FPSO's TRITON.

The applicability of thermo-chemical technologies for converging of associated gas in diesel-gas turbine installations for oil and gas floating units was considered in [8]. To describe the processes in the combustion chamber of a gas turbine engine working on synthesis gas, a mathematical model with detailed 35-reaction chemical mechanism was used. The disadvantage of the proposed in [8] calculation model is the impossibility of predicting the higher hydrocarbons burning-out, which play a significant role in the associated gas oxidation process.

It should be noted that despite the large amount of scientific research in the field of low-emission combustion chambers [9-11], the methodological and technical aspects of solving the problem of creating combustion chambers suitable for work with different gaseous fuels have not been developed so far.

\section{THE AIM OF THE STUDY}

The purpose of the work is to study the possibilities of organizing low-emission associated gas burning in the combustion chamber of a gas turbine engine with a capacity of $25 \mathrm{MW}$, which is the part of a floating production, storage and offloading system.

The object of the study is a workflow in a lowemission combustion chamber of a gas turbine engine operating on the associated gas. The subject of the study is the physicochemical characteristics of the processes of turbulent associated gas combustion, the flow aerodynamic structure in a low-emission gas turbine combustion chamber.

\section{THE MAIN MATERIAL}

Low-emission combustion chamber of a $25 \mathrm{MW}$ power gas turbine engine has a cannular design (Fig. 1), in which the idea of dry combustion of lean partially premixed mixture is used $[9,11]$. The main element of such a chamber is a burner, which consists of the two radial swirlers, one for each of two channels, behind which the annular mixing chambers are located. The air flow distribution between the first and second swirlers as a percentage of total air flow through the flame tube is about $12 \%$ to $61 \%$. Gaseous fuel is supplied through a set of holes in the vanes of radial swirlers of both first and second channels. 


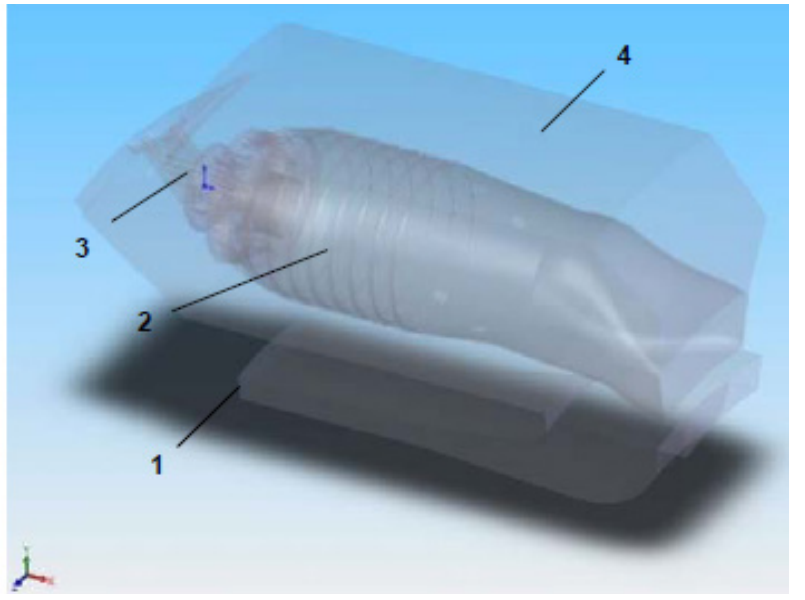

Fig. 1. "Lean-burn" gas turbine combustor:

1 - air after compressor; 2 - flame tube; 3 - burning device; 4 - casing

We suggest using a similar combustion chamber for the environmentally friendly combustion of associated gas during FSPO's operation.

It is known [12] that gaseous fuel may either be mixed with crude oil and enter the platform system through the same wells (associated gas) or be processed apart through special wells (non-associated gas). We will consider only associated gas since it is the most encountered case in crude oil offshore processing. Associated gas composition is presented in Table 1 [12]. As seen from Table 1, associated gas has a low content of hydrogen sulphide and carbon dioxide.

Table 1. Associated gas composition

\begin{tabular}{|c|c|}
\hline Chemical compound & Value, vol. \% \\
\hline $\mathrm{N}_{2}$ & 4.37 \\
\hline $\mathrm{CO}_{2}$ & 1.34 \\
\hline $\mathrm{H}_{2} \mathrm{~S}$ & 0.20 \\
\hline $\mathrm{CH}_{4}$ & 73.70 \\
\hline $\mathrm{C}_{2} \mathrm{H}_{6}$ & 6.10 \\
\hline $\mathrm{C}_{3} \mathrm{H}_{8}$ & 6.70 \\
\hline $\mathrm{n}_{-} \mathrm{C}_{4} \mathrm{H}_{10}$ & 2.48 \\
\hline $\mathrm{i}-\mathrm{C}_{4} \mathrm{H}_{10}$ & 1.41 \\
\hline $\mathrm{C} 5+$ & 3.70 \\
\hline
\end{tabular}

When carrying out three-dimensional calculations of the kinetic chemical scheme, the following model fuel composition (vol. fraction) was taken into consideration: $\mathrm{CH}_{4}=0.737, \mathrm{C}_{2} \mathrm{H}_{6}=0.061, \mathrm{C}_{3} \mathrm{H}_{8}=0.067, \mathrm{C}_{4} \mathrm{H}_{10}=0.0779$, $\mathrm{N}_{2}=0.0434, \mathrm{CO}_{2}=0.0134$.

The use of computational fluid dynamics (CFD) methods allows multivariate calculations and the provision of necessary information on the flow structure under non-isothermal conditions, on the main component's concentration distribution along the combustion chamber sections, taking into account the complexity of the combustion device's design.
The modeling of physicochemical processes in a gas turbine combustion chamber is based on solutions of the differential equations of mass, impulse and energy conservation for the multi-component, chemically reacting, turbulent system $[11 ; 13 ; 14]$.

The equation of mass conservation:

$$
\frac{\partial \rho}{\partial t}+\nabla \cdot(\rho \vec{v})=S_{m},
$$

where $\rho$ is the mass density, $t$ is the time period, $\vec{v}$ is the vector of local flow velocity, $S_{m}$ is the source term, which determines the mass introduced into the stream in any way.

The equation of momentum conservation:

$$
\frac{\partial}{\partial t}(\rho \vec{v})+\nabla \cdot(\rho \vec{v} \vec{v})=-\nabla p+\nabla \cdot\left(\tau_{s t}\right)+\rho \vec{g}+\vec{F},
$$

where $p$ is the static pressure, $\tau_{s t}$ is the stress tensor, $\rho \vec{g}$ and $\vec{F}$ are the gravitational body force and external body forces, respectively, the term $\vec{F}$ contains other modeldependent source terms such as user-defined sources.

The energy equation:

$\frac{\partial}{\partial t}(\rho E)+\nabla \cdot(\vec{v}(\rho E+p))=\nabla \cdot\left(k_{e f f} \nabla T-\sum_{j} \bar{J}_{j}+\left(\bar{\tau}_{e f f} \cdot \vec{v}\right)\right)+S_{h}$,

where $k_{\text {eff }}$ is the coefficient of effective conductivity, $\vec{J}_{j}$ is the diffusion flux of species $j$, the term $S_{h}$ includes heat of chemical reaction, or any other volumetric heat sources.

For aerodynamic structure prediction the RNG-based $\mathrm{k}-\varepsilon$-turbulence model has been used. Transport equations have similar form as a standard k- $\varepsilon$-model [13]:

$$
\begin{aligned}
& \frac{\partial}{\partial t}(\rho k)+\frac{\partial}{\partial x_{i}}\left(\rho k u_{i}\right)=\frac{\partial}{\partial x_{j}}\left[\left(\alpha_{k} \mu_{e f f}\right) \frac{\partial k}{\partial x_{j}}\right]+G_{k}+G_{b}-\rho \varepsilon-Y_{M}+S_{k} \\
& \frac{\partial}{\partial t}(\rho \varepsilon)+\frac{\partial}{\partial x_{i}}\left(\rho \varepsilon u_{i}\right)=\frac{\partial}{\partial x_{j}}\left[\left(\alpha_{\varepsilon} \mu_{e f f}\right) \frac{\partial \varepsilon}{\partial x_{j}}\right]+C_{1 \varepsilon} \frac{\varepsilon}{k}\left(G_{k}+C_{3 \varepsilon} G_{b}\right)-C_{2 \varepsilon} \rho \frac{\varepsilon^{2}}{k}-R_{\varepsilon}+S_{\varepsilon}
\end{aligned}
$$

In these equations, $G_{k}$ represents generation of a turbulence kinetic energy due to the mean velocity gradients, $G_{b}$ is the generation of turbulence kinetic energy due to buoyancy, $Y_{M}$ represents the contribution of the fluctuating dilatation in compressible turbulence to the overall dissipation rate. The quantities $\alpha_{k}$ and $\alpha_{\varepsilon}$ are the inverse effective Prandtl numbers for $k$ and $\varepsilon$, respectively, and $S_{k}$ and $S_{\varepsilon}$ are user-defined source terms.

The common source of the i-th chemical component which is obtained via the reaction $R_{i}$ is calculated as the sum of sources $N_{R}$ of Arrhenius reactions in which the components take part:

$$
R_{i}=M_{\varpi, i} \sum_{r=1}^{N_{R}} R_{i, r},
$$

where $M_{\varpi, i}$ is the molar mass of the i-th component, $R_{i, r}$ is the Arrhenius molar velocity of formation/ decomposition of the $\mathrm{i}$-th component in the reaction $r$. 


\section{ЕНЕРГЕТИЧНЕ МАШИНОБУДУВАННЯ №1-2020}

Let us consider chemical reactions $r$, formed as follows:

$$
\sum_{i=1}^{N} v_{i, r}^{\prime} \mathrm{M}_{i} \underset{k_{b, r}}{\stackrel{k_{f, r}}{\Leftrightarrow}} \sum_{i=1}^{N} v_{i, r}^{\prime} \mathrm{M}_{i}
$$

where $N$ is the amount of chemical components in the system, $v_{i, r}^{\prime}$ is the stoichiometric coefficient for the $\mathrm{i}$-th reagent in the reaction $r ; v_{i, r}^{\prime \prime}-$ is the stoichiometric coefficient for the $\mathrm{i}$-th product of the reaction $r ; \mathrm{M}_{i}$ is the symbol which means the i-th chemical component; $k_{f, r}$ is the constant of the direct velocity of the reaction $r ; k_{b, r}$ is the constant of the reverse velocity of the reaction $r$.

Summing the above equation is made for all the chemical components in the system, but only the substances which participate in the reaction as reagents and reaction products shall have not zero stoichiometric coefficients. The molar velocity of formation/ decomposition of the $\mathrm{i}$-th component in the reaction $r$ may be defined as follows:

$$
R_{i, r}=\Gamma\left(v_{i, r}^{\prime \prime}-v_{i, r}^{\prime}\right) \cdot\left(k_{f, r} \prod_{j=1}^{N_{r}}\left[C_{j, r}\right]^{\eta_{j, r}^{\prime}}-k_{b, r} \prod_{j=1}^{N_{r}}\left[C_{j, r}\right]^{\eta_{j, r}^{\prime \prime}}\right),
$$

where $N_{r}$ is the amount of chemical components in the chemical reaction $r ; C_{j, r}$ is the molar concentration of each $j$-th reagent and product in the reaction $r, \eta_{j, r}^{\prime}$ is the exponent of the velocity of the direct reaction for the $j$-th reagent and product in the reaction $r, \eta_{j, r}^{\prime \prime}$ is the exponent of the velocity of the reverse reaction for the $j$-th reagent and product in the reaction $r, \Gamma$ is influence of the third substances on the reaction velocity and is defined as follows:

$$
\Gamma=\sum_{j}^{N_{r}} \gamma_{j, r} C_{j}
$$

where $\gamma_{j, r}$ is the efficiency of third substances influencing the $j$-th component in the reaction $r$.

The velocity constant for the direct reaction $r$ is calculated using the Arrhenius expression:

$$
k_{f, r}=A_{r} T^{\beta_{r}} e^{-E_{r} / R T},
$$

where $A_{r}$ is a pre-exponential factor, $\beta_{r}$ is the temperature exponent, $E_{r}$ is the activation energy for the reaction, $R$ is the universal gas constant.

If the reaction is reversible, the constant of the reverse velocity is defined as follows:

$$
k_{b, r}=\frac{k_{f, r}}{K_{r}}
$$

where $K_{r}$ is the balance constant for the reaction $r$, which is defined from the formula:

$$
K_{r}=\exp \left(\frac{\Delta S_{r}^{0}}{R}-\frac{\Delta H_{r}^{0}}{R T}\right) \cdot\left(\frac{p_{a t m}}{R T}\right)^{\sum_{R=1}^{N_{R}}\left(v_{j, r}^{\prime \prime}-v_{j, r}^{\prime}\right)}
$$

where $p_{\text {atm }}$ is atmosphere pressure, and the expressions under the exponent mean the change of Gibbs energy.

It should be mentioned that this way to consider the influence of chemical kinetics on turbulent combustion is fair only for simple (global) combustion mechanisms. It is connected with the specifics of distribution of the turbulence level in the flow. In order to have an opportunity to use detailed chemical combustion mechanisms in the turbulent flows it is necessary to make the following assumption: the reactions take place in small turbulent structures called small-scaled reactors $[11 ; 15]$. In this model they are the constant-pressure reactors for which the initial conditions are defined by the components concentration and cell temperature. The reactions velocities are defined via the Arrhenius equation and numerically integrated by special algorithm.

Then the molar velocity of formation/decomposition of the i-th component in the reaction is:

$$
R_{i}=\frac{\rho\left(\xi^{*}\right)^{2}}{\tau^{*}\left[1-\left(\xi^{*}\right)^{3}\right]}\left(Y_{i}^{*}-Y_{i}\right)
$$

where $\xi^{*}=C_{\xi}\left(\frac{v \varepsilon}{k^{2}}\right)^{\frac{1}{4}}$ is the size of a small-scale reactor, which depends on kinematic viscosity $v$, kinetic turbulence energy $k$ and the dissipation velocity of the kinetic turbulence energy $\varepsilon$, and the constant $C_{\xi}=2.1377$, $\tau^{*}=C_{\tau}\left(\frac{v}{v}\right)^{\frac{1}{2}}$ is the time within which a reaction in the reactor takes place, $C_{\tau}=0.4082$ is the constant, $Y_{i}^{*}$ is the mass fraction of the $\mathrm{i}$-th reagent in the reactor after time $\tau^{*}$ finishes.

Two basic models can be used to calculate the associate gas burning processes in a gas turbine combustion chamber: the first one is the FR / ED (Finite-Rate / EddyDissipation) model - a combination of the model that takes into account the effects of the chemical reactions rate finiteness and model for the eddy dissipation [9]; the second one is the EDC (Eddy-Dissipation-Concept) model - an extended model of turbulent eddy dissipation, which includes low-level modeling of chemical processes of fuel oxidation under the conditions of the interaction of a flame with turbulent flow perturbations.

Since at present the detailed mechanisms of higher hydrocarbons are not yet sufficiently developed, in order to reduce the computational resources in the presented study, the FR / ED combustion model was selected.

In the calculations, the following six chemical reactions were taken into account:

1. $\mathrm{CH}_{4}+1.5 \mathrm{O}_{2}->\mathrm{CO}+2 \mathrm{H}_{2} \mathrm{O}$;

2. $\mathrm{CO}+0.5 \mathrm{O}_{2}->\mathrm{CO}_{2}$;

3. $\mathrm{CO}_{2}->\mathrm{CO}+0.5 \mathrm{O}_{2}$;

4. $\mathrm{C}_{2} \mathrm{H}_{6}+3.5 \mathrm{O}_{2}->2 \mathrm{CO}_{2}+3 \mathrm{H}_{2} \mathrm{O}$;

5. $\mathrm{C}_{3} \mathrm{H}_{8}+3.5 \mathrm{O}_{2}->3 \mathrm{CO}+4 \mathrm{H}_{2} \mathrm{O}$;

6. $\mathrm{C}_{4} \mathrm{H}_{10}+6.5 \mathrm{O}_{2}->4 \mathrm{CO}_{2}+5 \mathrm{H}_{2} \mathrm{O}$.

The Arrhenius rates for these reactions are presented in Table 2. 
Table 2. Arrhenius rates

\begin{tabular}{|c|c|c|c|c|c|}
\hline $\begin{array}{c}\text { Reaction } \\
\text { number }\end{array}$ & $\begin{array}{c}\text { Pre-exponential } \\
\text { factor }\end{array}$ & $\begin{array}{c}\text { Activation energy, } \\
\mathbf{j} / \mathbf{k g m o l}\end{array}$ & $\begin{array}{c}\text { Temperature } \\
\text { exponent }\end{array}$ & $\begin{array}{c}\text { Reagents rate } \\
\text { exponent }\end{array}$ & $\begin{array}{c}\text { Products rate } \\
\text { exponent }\end{array}$ \\
\hline 1 & $4.64 \mathrm{e}+09$ & $1.17 \mathrm{e}+08$ & -0.062 & $0.5 / 1.066$ & $0 / 0$ \\
\hline 2 & $3.97 \mathrm{e}+11$ & $7.68 \mathrm{e}+07$ & 0.215 & $1.258 / 1.756$ & 0 \\
\hline 3 & 602000 & $1.31 \mathrm{e}+08$ & -0.108 & 1.357 & $0 / 0$ \\
\hline 4 & $6.186 \mathrm{e}+09$ & $1.256 \mathrm{e}+08$ & 0 & $0.1 / 1.65$ & $0 / 0$ \\
\hline 5 & $5.62 \mathrm{e}+09$ & $1.256 \mathrm{e}+08$ & 0 & $0.1 / 1.65$ & $0 / 0$ \\
\hline 6 & $4.161 \mathrm{e}+09$ & $1.256 \mathrm{e}+08$ & 0 & $0.15 / 1.6$ & $0 / 0$ \\
\hline
\end{tabular}

The contours of static temperature in the combustion chamber longitudinal section during burning of natural and associated gases are presented in Fig. 2. In the transition from natural gas to associated gas, the general structure of the flame changes slightly. However, in the low-emission combustion chamber under consideration, the fueloxidizer ratios in both axial-radial swirlers change, which leads to the appearance of a high-temperature zone in the internal swirler region. Note that the redistribution of the excess air coefficients in the central part of the flame tube and in the periphery during of associated gas combustion is accompanied by an increase in the maximum local temperature: from 2210 to $2570 \mathrm{~K}$.
The distribution of the products of complete combustion $\mathrm{CO}_{2}$ (Fig. 3) is identical to the temperature distribution over the flame tube sections.

The temperature distribution in the outlet section of the combustion chamber during the combustion of various fuels is shown in Fig. 4. There is a pronounced region with maximum temperatures in the central zone, and the mass-weighted average temperature at the combustion chamber outlet equals to $1549.0 \mathrm{~K}$ at natural gas burning and $1544.5 \mathrm{~K}$ at associated gas burning (i.e. approximately the same).

The temperature distributions shown above determine the formation of nitrogen oxides in the combustion

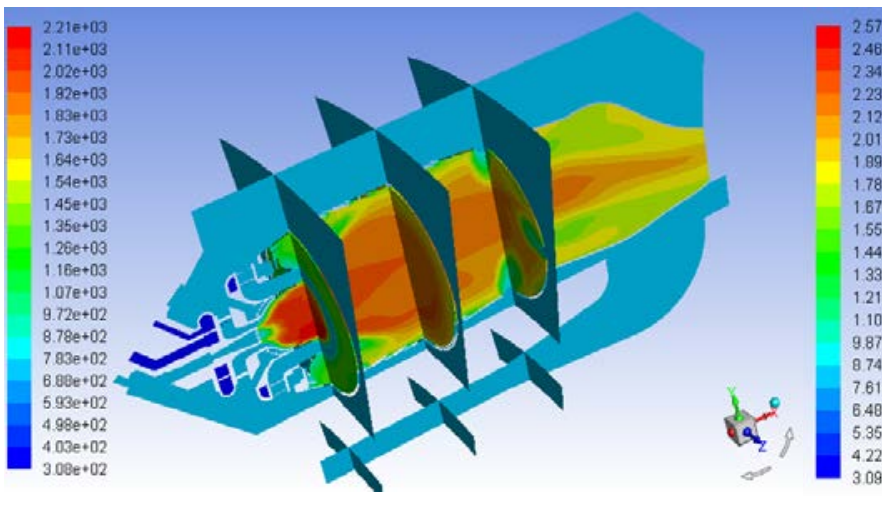

a

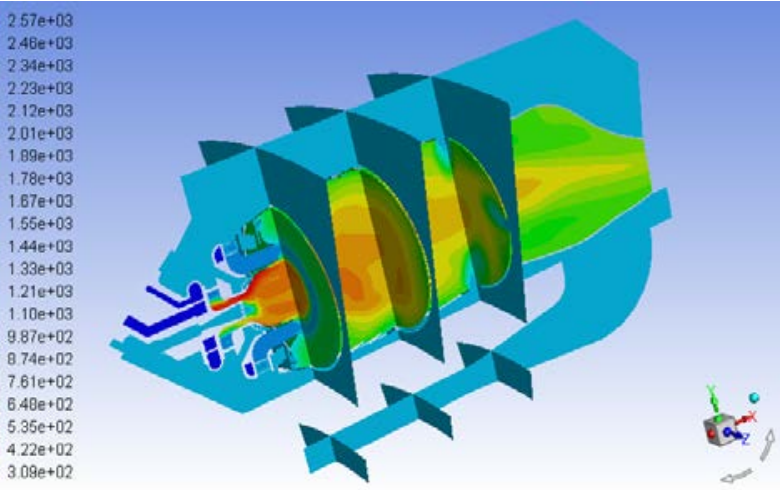

$\mathrm{b}$

Fig. 2. Contours of static temperature, $\mathrm{K}$, in the longitudinal section: $\mathrm{a}$ - natural gas; $\mathrm{b}$ - associated gas

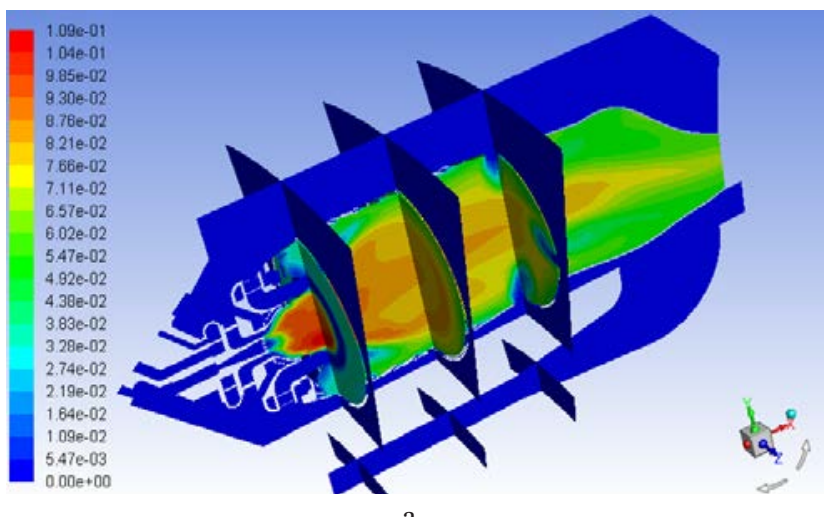

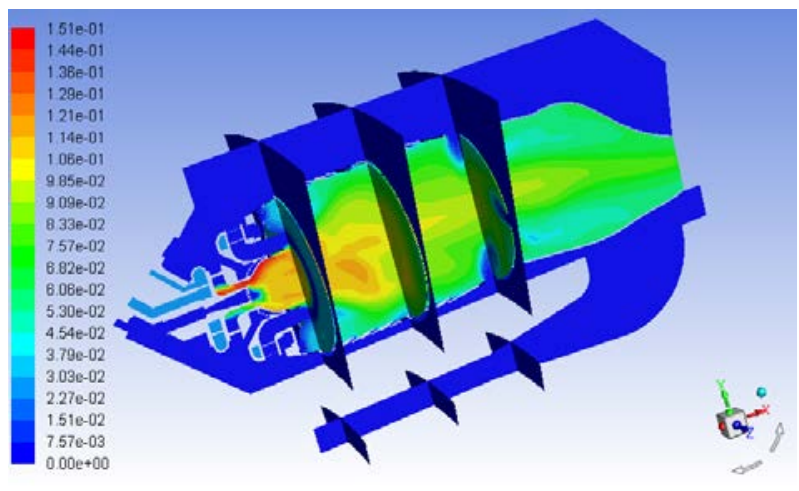

Fig. 3. Contours of mass fraction of $\mathrm{CO}_{2}$ in the longitudinal section: $\mathrm{a}$ - natural gas; $\mathrm{b}$ - associated gas 


\section{ЕНЕРГЕТИЧНЕ МАШИНОБУДУВАННЯ №1—2020}

chamber (Figs. 5 and 6). Note that, when modeling the formation and decomposition of nitrogen oxides, the following pathways taken into account: thermal $\mathrm{NO}_{\mathrm{x}}$, prompt $\mathrm{NO}_{x}, \mathrm{~N}_{2} \mathrm{O}$ intermediate.

As a result of a sufficiently large increase in the maximum temperature in the combustion chamber, the calculated emission of nitrogen oxides in the outlet flame tube section increases significantly from 6.71 to $67.52 \mathrm{ppm}$.

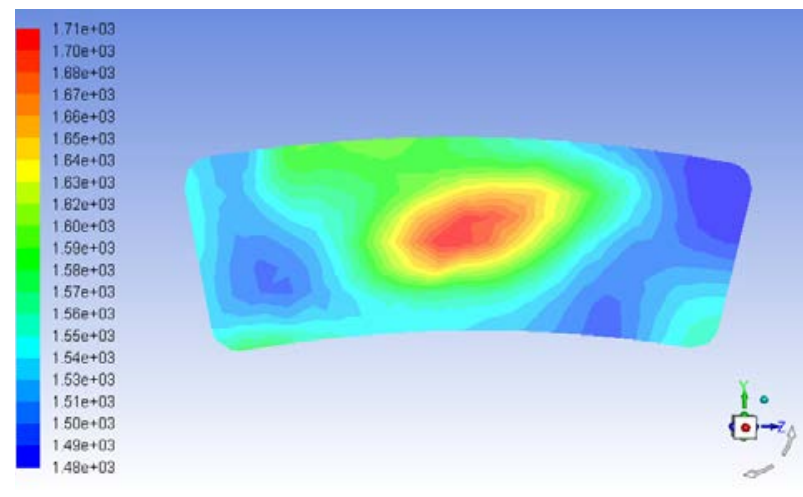

a

Fig. 4. Contours of static temperature, $\mathrm{K}$, at the combustor chamber outlet: $\mathrm{a}$ - natural gas; $\mathrm{b}$ - associated gas
The distribution of carbon oxide $\mathrm{CO}$ over the flame tube sections is shown in Fig. 7. Due to the increased flow rate of associated gas through the burner device channels (as compared to the natural gas flow rate), the burning out of hydrocarbons slows down, which leads to a slight increase in the carbon oxide content in the outlet section: from 16.75 (natural gas) to $20.29 \mathrm{ppm}$ (associated gas).

Figures 8 and 9 show the contours of the mass fractions of the hydrocarbon components of the fuel:

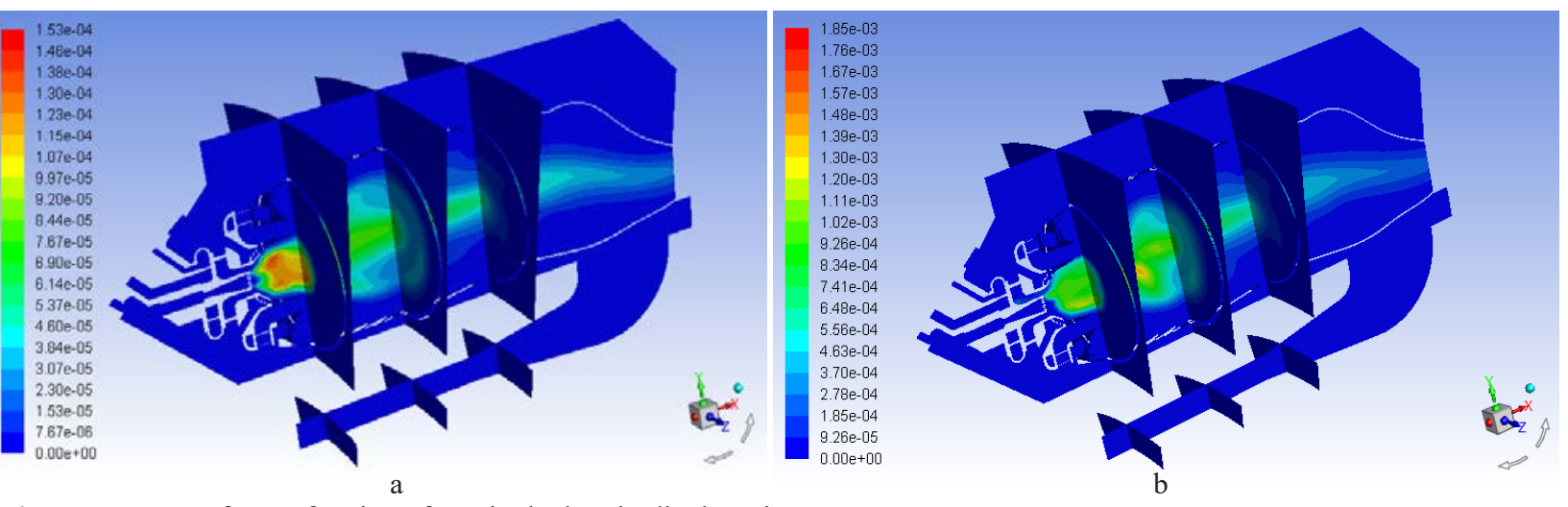

Fig. 5. Contours of mass fraction of NO in the longitudinal section: $\mathrm{a}$ - natural gas; $\mathrm{b}$ - associated gas

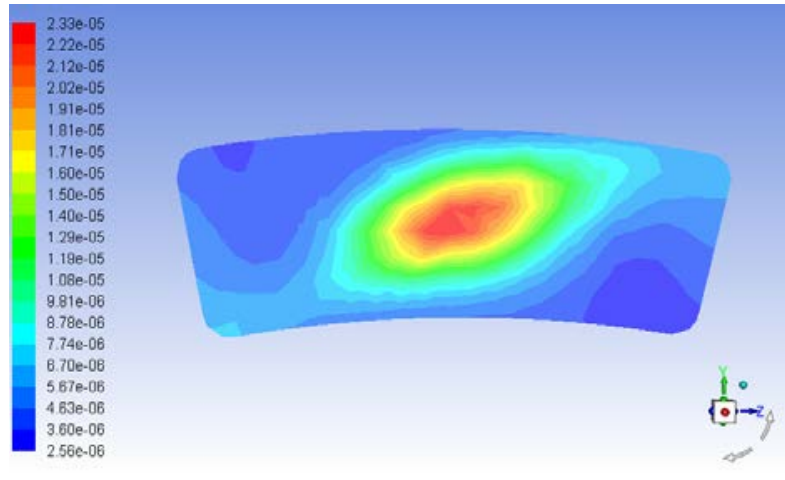

a

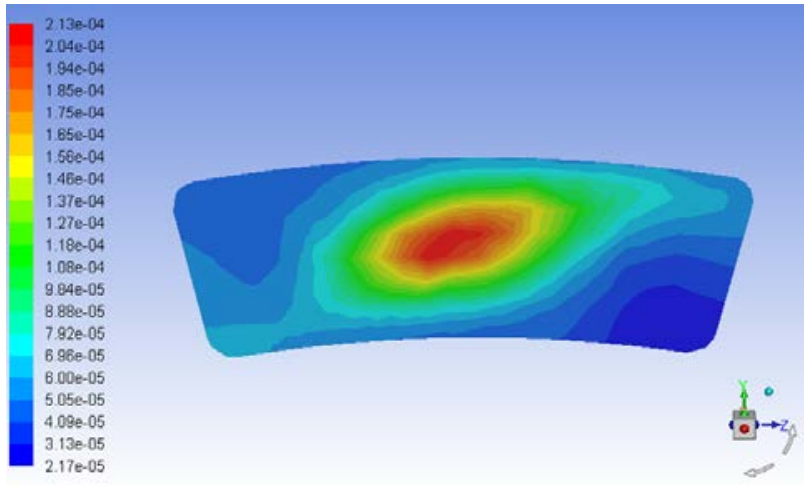

b

Fig. 6. Contours of mass fraction of NO at the combustor chamber outlet: $a$ - natural gas; $b$ - associated ga 


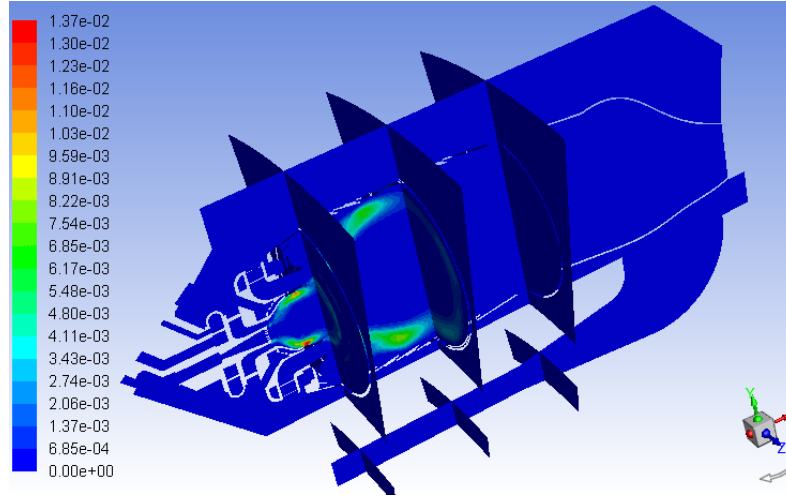

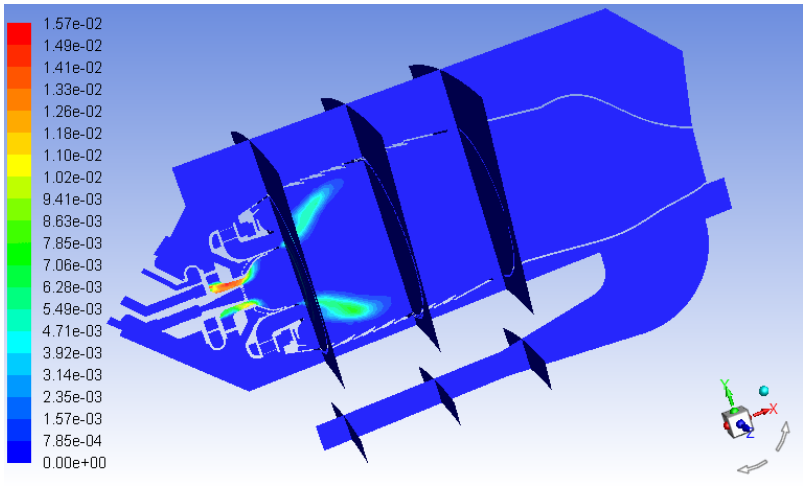

b

Fig. 7. Contours of mass fraction of $\mathrm{CO}$ in the longitudinal section: $\mathrm{a}$ - natural gas; $\mathrm{b}$ - associated gas

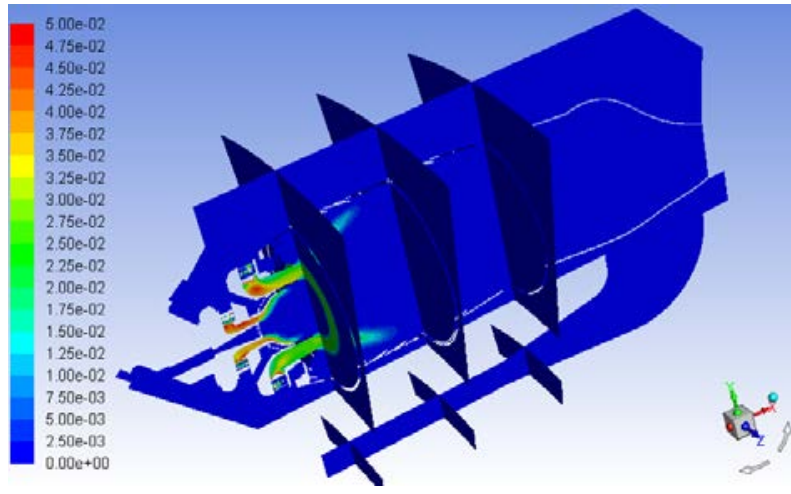

$a$

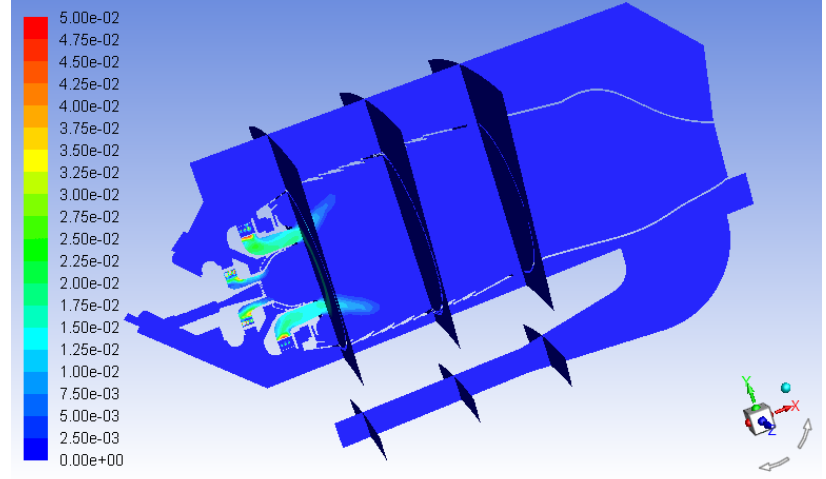

$\mathrm{b}$

Fig. 8. Contours of mass fraction of $\mathrm{CH}_{4}$ in the longitudinal section:

$\mathrm{a}$ - natural gas; $\mathrm{b}$ - associated gas

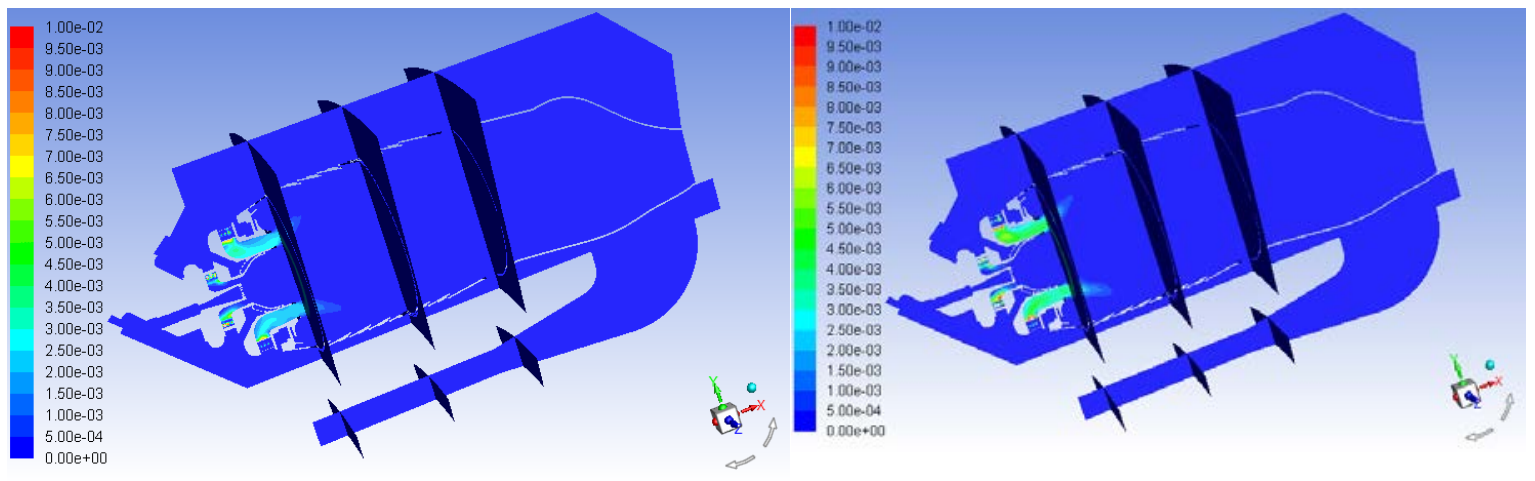

a

b

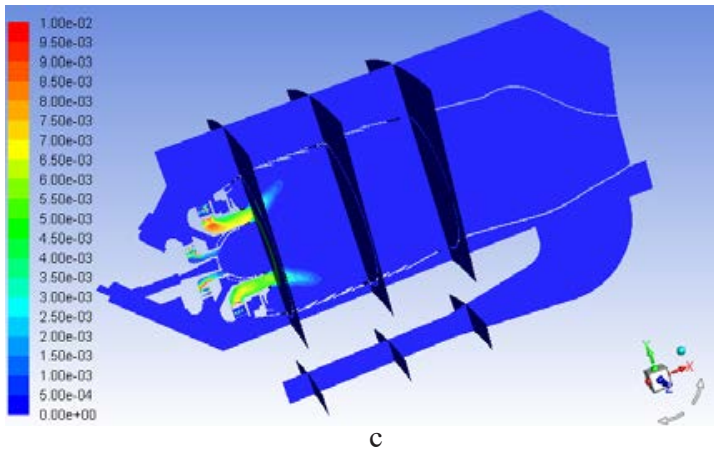

Fig. 9. Contours of mass fraction of $\mathrm{C}_{2} \mathrm{H}_{6}(\mathrm{a}), \mathrm{C}_{3} \mathrm{H}_{8}(\mathrm{~b}), \mathrm{C}_{4} \mathrm{H}_{10}$ (c) during associated gas combustion 


\section{ЕНЕРГЕТИЧНЕ МАШИНОБУДУВАННЯ № 1 2020}

methane $\mathrm{CH}_{4}$ (Fig. 8 - for natural and associated gases) and higher hydrocarbons - ethane $\mathrm{C}_{2} \mathrm{H}_{6}$, propane $\mathrm{C}_{3} \mathrm{H}_{8}$, butane $\mathrm{C}_{4} \mathrm{H}_{10}$ (Fig. 9 - for associated gas).

The obtained data show that when the considered gas turbine engine with a capacity of $25 \mathrm{MW}$ is switched from natural gas to associated gas, which has a higher content of higher hydrocarbons and lower methane concentration, a decrease in the combustion chamber's environmental performance is observed. This is especially true for nitrogen oxides emission, which begins to exceed the levels established by Directive 2010/75/EU of the European Parliament and of the Council of 24 November 2010 on industrial emissions (integrated pollution prevention and control).

Thus, in order to satisfy the standards for emissions of toxic components, it is necessary to modify the design of the low-emission combustion chamber when transferring it to associated gas. This is the subject of further research.

\section{CONCLUSIONS}

Investigations of the possibilities of organizing low-emission associated gas burning in the combustion chamber of a gas turbine engine with a capacity of $25 \mathrm{MW}$, which is the part of a floating production, storage and offloading system, have been carried out.

A mathematical model of a low-emission gas turbine combustion chamber has been developed, which allows predicting the environmental parameters of a fuel-burning device when using associated gas.

Three-dimensional CFD calculations of the physicochemical parameters of the low-emission gas turbine combustion chamber operating on natural and associated gases were carried out.

The obtained results showed certain deterioration in the environmental parameters of the combustion chamber when switching from natural to associated gas and the need for further modification of the combustion chamber with lean and partially premixed mixture of fuel and air when using associated gas on the FPSO vessels.

\section{REFERENCES}

[1] Offshore Magazine (2018). OTC 2018: FPSO Market Recovery Under Way, Says EMA Report. Retrieved from: https://www.offshore-mag.com/production/article/16804111/otc-2018-fpso-market-recovery-under-waysays-ema-report.

[2] Offshore Technology (2018). Report: 55 FPSOs to Start Operations by 2022. Retrieved from: https://www.offshore-technology.com/news/report-55-fpsos-start-operations-2022/.

[3] ENI (2016). Block 15-06 East Hub Development Project. Retrieved from: https://www.eni.com/docs/en_IT/ enicom/publications-archive/publications/brochures-booklets/countries/brochure_eni_angola_ese_web.pdf.

[4] EU, Directive 2010/75/EU of the European Parliament and of the Council of 24 November 2010 on industrial emissions (integrated pollution prevention and control), 59-61.

[5] OCYAN (2017). FPSO Pioneiro de Libra. Retrieved from: http://www.ocyansa.com/en/fleet/fpso-pioneiro-delibra.

[6] Offshore Technology (2018). Triton Oil Field, North Sea Central. Retrieved from: https://www.offshoretechnology.com/projects/triton/.

[7] Cherednichenko O., Serbin S., Dzida M. (2019). Investigation of the Combustion Processes in the Gas Turbine Module of an FPSO Operating on Associated Gas Conversion Products. Polish Maritime Research, vol. 26, no. 4 (104), 149-156.

[8] Cherednichenko O., Serbin S., Dzida M. (2019). Application of thermo-chemical technologies for converging of associated gas in diesel-gas turbine installations for oil and gas floating units. Polish Maritime Research, vol. 26, no. 3 (103), 181-187.

[9] Serbin S., Kozlovskyi A., Burunsuz K., Radchenko R. (2019). Study of burning stability in low emission gas turbine combustor (Book Chapter). In: Contemporary Issues of Heat and Mass Transfer. Monography No. 360 of the faculty of Mechanical Engineering: Koszalin University of Technology, Poland, ISSN 0239-7129, 747-766.

[10] Serbin S., Burunsuz K., Goncharova N., Radchenko A., Radchenko R. (2019). Investigations of sulfur oxides formation and decomposition in a gas turbine combustor with steam injection (Book Chapter). In: Contemporary Issues of Heat and Mass Transfer. Monography No. 360 of the faculty of Mechanical Engineering: Koszalin University of Technology, Poland, ISSN 0239-7129, 731-746.

[11] Serbin S. I., Matveev I. B., Mostipanenko G. B. (2011). Investigations of the Working Process in a "LeanBurn" Gas Turbine Combustor with Plasma Assistance. IEEE Transactions on Plasma Science, vol. 39, issue 12, 3331-3335

[12] Nguyena T. V., Elmegaarda B., Pierobona L., Haglinda F., Breuhausb P. (2012). Modelling and analysis of offshore energy systems on North Sea oil and gas platforms. 53-rd International Conference of Scandinavian Simulation Society, Reykjavik, Iceland, 1-16. 
[13] Choudhury D. (1993). Introduction to the Renormalization Group Method and Turbulence Modeling. Fluent Inc. Technical Memorandum TM-107.

[14] Launder B. E., Spalding D. B. (1972). Lectures in Mathematical Models of Turbulence. Academic Press, London.

[15] Burunsuz K. S., Kuklinovsky V. V., Serbin S. I. (2019). Investigations of the emission characteristics of a gas turbine combustor with water steam injection. Refrigeration Engineering and Technology, 55(2), 77-83.

(C) S. I. Serbin, Wang YunFei

Дата надходження статті до редакції: 05.03.2020

Дата затвердження статті до друку: 17.04.2020 